Предраг Петровић

Универзитет у Београду

Филолошки факултет

pedja611@yahoo.com

https://doi.org/10.18485/ai_savremeni_roman.2020.ch1

821.163.41.09-31"20"

Оригинални научни рад

\title{
СРПСКИ РОМАН У НОВОМ ВЕКУ
}

Стваралачки токови у српском роману на прелазу столећа посматрају се у односу на успостављену постмодернистичку парадигму и то као њен наставак, модификација или превазилажење. Српска књижевност, као и друштво, у новом веку још увек се опсесивно бави неким болним питањима с краја прошлог столећа. Теме емиграције, кризе вредности, ратова, дестабилизованог индивидуалног и националног идентитета, бомбардовања, бука и бес историје доминантне су у нововековном роману.

Кључне речи: савремена књижевност, роман, поетика, постмодернизам, историја.

Могућности поетичког одређења савременог српског романа тичу се одговора на неколико питања која проистичу једно из другог. Најпре, који је то временски опсег о којем говоримо, односно када почиње савременост и шта јој, заправо, претходи; даље, да ли се она у српској књижевности може прецизније периодизацијски и појмовно именовати, те коначно, које су то њене водеће стваралачке тенденције и аутори?

Са сличним питањима суочавају се и историчари друштвених и политичких збивања, поготову они који 
инсистирају на, у историји књижевности и културе добро познатом, неподударању календарских и смисаоних граница векова. Тако, утицајни британски историчар Ерих Хобсбаум у књизи Доба екстрема (1994) „кратки двадесети век“ одређује као епоху мегасмрти која се као кохерентна целина може успоставити у распону од Првог светског рата, односно од Октобарске револуције до пада Берлинског зида, односно распада Совјетског Савеза. Наспрам дугог деветнаестог века, чији је суштински почетак Француска буржоаска револуција а природни крај Велики рат који је сахранио дотадашње западно друштво, ово је, дакле, кратки двадесети век чије се трајање „подудара са животним веком државе рођене у Октобарској револуцији“ (Hobsbaum 2002: 48). Иако је оваква визија века омеђеног судбином једне државе, идеологије (комунизам) и друштвеног система (социјализам) била оштро критикована у западним земаљама, она може бити важна за разумевање токова српске историје и културе новог доба, поготову што Хобсбаум велику пажњу посвећује рату на простору бивше Југославије, у контексту трагичног и поражавајућег смираја прошлог века. Сличног мишљења о трајању и смислу двадесетога столећа био је и утицајни француски филозоф Алан Бадју који, успостављајући век као објекат мишљења, његов симболични завршетак види у неколико могућих преломних тачака - пад Берлинског зида, пуштање у рад интернета, мапирање генома, формирање Европске уније, али, ипак, предност даје апокалиптичном здруженом ишчезнућу човека и Бога. Заправо, према Бадјуу, на почетку смо постхуманистичке ере јер „монотеистички Бог мртав је већ одавно, сигурно већ неких двеста година, док човек хуманизма није преживео двадесети век“ (Badiou 2007: 155). На трагу оваквих размишљања о смисаоним 
границама века могло би се размишљати о српском прошлом столећу чији пуни распон би био од мајског преврата 1903. до октобарског преврата 2000. године.

Одређујући српску књижевност прве деценије двадесетог века Јован Скерлић се у завршници своје Историје нове српске кюижевности (1914) нашао пред изазовом који очекује сваког историчара књижевности који покушава да издвоји и одреди водеће поетичке тенденције актуелне, текуће књижевности и да, кроз неизбежна уопштавања, успостави могућу синтезу. Посао историчара књижевности ту се заправо сустиче са пољем деловања књижевног критичара који вреднује савремену продукцију. Издвајајући индивидуализам као једну од доминантних одлика стваралаштва на почетку века, Скерлић вели да су у ранијим књижевним периодима, понајпре у доба романтизма и реализма, чак и они најоригиналнији аутори имали блиску идеологију, сличан књижевни укус и начин рада, те, коначно, били у кругу препознатљивог и јединственог духовног утицаја. „Данас није више тај случај. Између појединих писаца могу се ухватити извесне заједничке црте, али сваки има своје засебно духовно и књижевно обележје, сваки иде својим путем, да је тешко, готово немогуће, уопштавати их и давати им опште карактеристике. То није анархија у духовима и књижевном раду, но слобода уметности и самосталан књижевни рад. Цело доба изгледа да нема нарочиту особеност и одређене црте као што је то био случај романтичарских шездесетих и реалистичких седамдесетих година, али у накнаду за то, модерни српски писци су оригиналнији, одређенији и већма своји“, закључује Скерлић (Скерлић 1953: 424). Чини се да би се слична оцена могла изрећи и када је реч о српским књижевницима на почетку двадесет и првог века. Међутим, данас је исто тако јасно да су мно- 
ге Скерлићеве недоумице везане за одређење српске књижевности почетком прошлог века у међувремену разрешене па сада говоримо о периоду модерне, од деведесетих година деветнаестог века до 1917, који нам се са ове, стогодишње дистанце, уз уважавање свих особености, индивидуалности и оригиналности указује као прилично целовито и кохерентно књижевноисторијско раздобље.

У том смислу, разумљиво је да ће са веће временске дистанце појаве, аутори и тенденције српске књижевности на почетку двадесет првог века изгледати јасније него што се то можда данас чини. Ипак, покушаји синтеза, периодизацијских одређења и поетичких уопштавања савремене српске књижевности већ постоје. Поменимо књиге Кратка историја преобила (2009) Тихомира Брајовића, Иреалистичко доба: српска книжевност од 1990. до 2010. (2015) Стојана Ђорђића или Повратак причи (2017) Марка Недића. Тежња ка профилисању одређених поетичких токова у савременој српској прози видна је и у књигама страних аутора: Поетика форме у прози српског постмодернизма (2013) Але Татаренко, Мапе времена (2015) Силвије Новак Бајцар и Духови круже Србијом (2017) Дејвида Нориса.

Да ли у књижевности постоји нека препознатљива, на првом месту, поетичка прекретница (поред оних већ поменутих које долазе из политичке и друштвене историје) која окончава двадесети век и означава почетак новог доба? Најпре бисмо могли навести чувену оцену париског критичара Филипа Третјака да је Павићев Хазарски речник (1984) прва књига трећег миленијума. Међутим, поетички, али исто тако и политички разлози утицали су на то да Павићево дело буде скрајнуто, можда не толико у српској или, рецимо, руској колико у америчкој и европским књижевностима. Тенденциоз- 
на и злонамерна читања која су од половине деведесетих година, поготову у немачкој критици, у Павићевим романима налазила одјеке тобожњег великосрпског национализма, више сведоче о незавидној позицији у којој су се Србија и њена култура нашле на измаку прошлог века. Међутим, судбина Павићеве прозе свакако је повезана и са токовима постмодернизма (иако се не може свести само на то) па је зато оправдано тврдити да је извесна маргинализација овога аутора у вези са превладавањем и одустајањем од постмодернистичке парадигме у годинама двадесет и првог века, поготову од њене наративне ars combinatorie. Хазарски речник означио је почетак хипертекстуалног доба којим данас суверено влада интернет као глобални електронски хипертекст, али та нова епоха као да је „појела“ свог књижевног творца. Чини се да се аутори и читаоци, засићени вишедимензионалном нелинеарном мрежом комуникација, данас враћају неким искуствима ранијих, модернистичких наративних форми, мада је наравно јасно да тај повратак не може бити ни једноставан ни једнозначан. ${ }^{1}$

У одређењу савременог доба српског романа мора

1 Управо један од водећих постмодернистичких књижевника и творац концепције отвореног дела, Умберто Еко, на самом почетку двадесет и првог века критички ће преиспитати књижевне домете хипертекста и нових читалачких могућности. Не оспоравајући му креативност и слободу, Еко у књижевном хипертексту ипак види илузију која нам ускраћује можда најважнију спознају живота. „Функција непроментивих прича управо је у томе: упркос свим нашим жељама да изменимо судбину, приморани смо да својеручно дотакнемо немогућност да се она измени. И отуда, о каквом год збивању приповедале, оне приповедају и о нама, због тога их читамо и волимо. Потребна нам је њихова строга репресивна лекција. Хипертекстуална проза може нас учити слободи и креативности. То је добро, али није све у томе. Већ створене приче уче нас како да умремо“" (Eko 2002: 20). 
се, дакле, поћи од постмодернизма. Иако овај појам и даље фигурира као могуће одређење актуелних књижевних токова јасно је да је он у многоме изгубио онај значај који је задобио током осамдесетих, када је у прози Данила Киша, Милорада Павића, Борислава Пекића и других, млађих аутора, постепено стекао поетички легитимитет, да би потом у Антологији српске прозе постмодерног доба (1991) Александра Јеркова добио потпуну теоријску и појмовну самосвест. Говорећи десет година касније о српској прози на прелазу из двадесетог у нови век, други велики апологета постмодернизма, Сава Дамјанов, истиче да се „појавила нова генерација писаца за коју постмодерна проза представља већ испричан и исписан феномен, мада се и они у својим делима на неки начин ослањају на њене премисе” (Дамјанов 2012: 180). Зато је сасвим разложно да се поетички токови у српској књижевности, првенствено у прози, на прелазу столећа посматрају у односу на постмодернистичку парадигму - као њен наставак, модификација, превазилажење или, пак, одбацивање. Ипак, за разлику од прозе, нешто другачија ситуација је у поезији где постмодернизам није добио тако видно и значајно одређење, иако се може говорити о његовом присуству у познијој лирици Стевана Раичковића, Ивана В. Лалића или Миодрага Павловића.

Међутим, јасно је да на прелазу векова настављају да стварају и аутори старије генерације чија се поетика не може довести у везу с постмодернизмом. Проза Добрице Ћосића или Драгослава Михаиловића представља дозревање оних уметничких квалитета које су ови аутори успоставили деценијама уназад. У том смислу за одређивање профила савремене српске књижевности важнији су примери изразитијих поетичких промена које су настале у опусу већ афирмисаних ауто- 
ра, рецимо у романима Милисава Савића Прини и сербски списатељь (2008) и La sans pareille (2015) у којима је заокружен прелаз овога аутора из оквира стварносне прозе ка постмодернизму. Некада могу бити индикативна не само стваралачка него и жанровска преусмерења, рецимо у случају песника и књижевног критичара Александра Петрова који се у новом веку афирмише као романописац отварајући, за нови век српске прозе карактеристично, виђење историје из исповедне и аутофикционалне визуре. Коначно, у сваком књижевном периоду има значајних аутора особеног израза који стоје попут усамљених врхова, несводљивих на доминантне токове, и то су углавном писци богате и заплетене језичке имагинације, какви су на прелазу векова Мирослав Јосић Вишњић и Радован Бели Марковић.

Али, ако се вратимо постмодернизму, као магистралном току који је обележио српску прозу у последњим деценијама прошлога века, за мапирање важних стваралачких тенденција чини се важна 1988. година када се јасно очитује раслојавање постмодерне парадигме у три могућа тока која ће обележети последњу деценију двадесетог а чије последице се могу пратити и у новом веку. Први је историографска метафикција, репрезентована Пекићевим Новим Јерусалимом као својеврсном синтезом Пекићевог али исто тако и дотадашњег српског постмодернистичког приповедања које је било у знаку аутопоетичког промишљања репрезентоване прошлости али и домета сваког историјског знања. Исте године појављује се Басарина Фама о бициклистима која књижевно виђење историје усмерава ка наглашеној карневализацији и сатири што ће остати препознатљиво обележје Басарине прозе до данас. Коначно, 1988. појављује се и Албахаријев роман Цинк и збирка приповедака Једно- 
ставност које постмодернизам успостављају у поетичком моделу минимализма. ${ }^{2}$ У оквиру ове три линије раслојавања постмодернизма могу се пратити кључни токови српске прозе на прелазу векова. У знаку историографске метафикције појавиће се најбоља романескна остварења последње деценије прошлога века - Судбина и коментари (1993) Радослава Петковића и изванредна прозна завршница века - Опсада иркве Светог спаса (1997) и Ситничарнииа Код Срећне руке (2000) Горана Петровића. Управо би се Ситничарница могла назвати и последњим великим постмодернистичким романом српске књижевности зато што се у њој до крајњих граница доводи она, од Борхеса и Калвина до Ека и Павића, карактеристична постмодерна фантастика занована на кретању ликова-читалаца кроз различите онтолошке равни могућих светова.

Како се у раслојавању постмодернистичке парадигме могу тражити упоришта нових приповедачких стратегија најбоље говоре промене у Албахаријевим романима из деведесетих година, што ће постати окосница једног особеног типа прозе који ће обележити српску књижевност почетком новог века. Наиме, метанаративни минимализам из Цинка постепено ће се отварати ка искуству историје, како оне актуелне, повезане с распадом Југославије, тако и оне старије која се тиче прогона Срба и Јевереја у Другом светском рату. Ауторова неформална, добровољно-изгнаничка трилогија (Кратка книга, Снежни човек и Мамаи) засноваће у савременој српској прози тип емигрантског дискур-

2 Линда Хачион у историјској метафикцији види кључно обележје постмодерних романа (Нас̌ion 1996: 178-208). Аналогно овом појму Тихомир Брајовић говори о Басариним романима као „Историографској карневализацији“ и Албахаријевој прози као „историографском хомологизму“ (Брајовић 2009). 
са о јунацима који свој нови индетитет покушавају да заснују у егзилу, лутајући Европом и Америком или, који, пак, добровољно постају маргиналци, аутсајдери на рубу друштва. На таквом трагу појављују се на самом почетку новог века романи Владимира Тасића Опрочтајни дар (2001) и Киша и хартија (2004) у којима проговара сензибилитет дигиталног доба кроз наглашено интересовање за информационе технологије, виртуелну стварност и мултимедијалну уметност. Управо поводом романа Киша и хартија Новица Петковић ће приметити да у савременом српском роману поново легитимитет стичу расељена лица из Романа o Лондону Милоша Црњанског (Петковић 2007). А слично искуство Албахаријевих и Тасићевих јунака имају приповедачи и протагонисти романа Драгана Великића, Срђана Ваљаревића и Слободана Тишме. Таква егзистенцијална позиција, емиграната или аутсајдера, нужно постаје и поетичка, производећи различите облике исповедног приповедања и аутобиографског дискурса, када приповедач, проглашавајући себе субјектом властитог разумевања, проблематизује индивидуални идентитет у мање или више наглашеном контексту друштвеног и културолошког слома на крају столећа. Усамљеност модерног јунака и свет његове (не)изговорене интиме на позадини историјских пропасти и генерацијских разочарања, постају поетичко средиште романа у новом веку. „Како се иде са Истока на Запад, тако се самоћа увећава. Сви би само да конзумирају", вели један од јунака Великићевог Руског прозора (2007). Увећавањем усамљености и конзументских навика све више се умањује способност наше културе да приче чује и разуме. Ипак, могућност емпатије и интимног препознавања у Тасићевом роману Киша и хартија остварена је евоцирањем стихова „Суматре“ Милоша Црњанског. 
Суматраистичка визија изгубљене завичајности али и проналажења универзалног разумевања међу људима нашла је у српском роману свој нови израз.

Једно од препознатљивих обележја српског романа у новом веку је управо превазилажење постмодернизма кроз наглашенију комуникацију са модернистичким књижевним искуством Милоша Црњанског, Иве Андрића али и Данила Киша, али Киша првенствено из Породичне трилогије. Ти процеси су евидентни и у прози Владана Матијевића који од збирке приповедака Прилично мртви (2000) до романа Врло мало светлости (2010) успоставља могућу везу са црним таласом српске прозе и филма из двадесетог века, у том смислу и са прозом Миодрага Булатовића, по наглашеним моментима апсурда и гротеске. Импресивни историјски роман Александра Гаталице Велики рат (2012) ближи је оној модернистичкој светскоисторијској позорници него постмодернистичкој историографској метафикцији. У романима Радована Белог Марковића уочљива је веза са приповедачким наслеђем „тамног вилајета“ Момчила Настасијевића или гробљанском хроником Исидоре Секулић. Нешто од поступка кинематографског приповедања, карактеристичног за српски роман након Првог светског рата, активира Владимир Кецмановић у до данас најбољем српском роману са тематиком грађанског рата у Босни, Топ је био врео (2008).

Занимљиво је да нека појмовна и поетичка одређења овог периода који у књижевности наступа, или би могао да наступи, након постмодернизма, управо истичу тај повратак неким искуствима модернистичке уметности или, пак, у креативној синтези модернизма и постмодернизма виде будућност литературе у новом веку. Реч је првенствено о ставовима руског теоретичара Михаила Епштејна, који говори о протомодернизму 
и трансмодернизму који у савременој култури треба да смене префикс пост. „Ако прото означава отвореност и унапред нерешену будућност, онда транс утврђује континуитет будућности и прошлости, која као да прекорачује преко зоне отуђења, ироније, пародије, да би поново прешла у намеру да означи свој обновитељски статус могућног“ (Епштејн 1998: 140). Епштејн ће говорити и о новој сентименталности, док други аутори помињу хипермодернизам као наследника постмодернизма наглашавајући везе с хипертекстом и хиперпростором дигиталног доба.

Нова економија писања, али и нове стратегије читања могу се посматрати и у вези с развојем информационих технологија односно облицима преноса, чувања и манипулисања знањима. Могућност романа да своју поетику заснује у дослуху са искуством интернета отворена је крајем прошлога века у фикционалној прози и есејима Милорада Павића. Међутим, чини се да у овом веку роман напушта неке препознатљиве одлике постмодерне парадигме, као што су у Павићевим текстовима били нелинеарно писмо и наглашена интерактивна улога читаоца. Ипак, савремени медији и облици комуникације и даље остају, али на другачији начин, присутни у наративним стратегијама. Тако се у романима Врло мало светлости Владана Матијевића и Сасвим скромни дарови (2011) Угљеше Шајтинца активира форма (заборављеног) епистоларног романа али кроз размену електронске поште. Интернет као доминантан извор знања и информација обликује енциклопедијско свезнање и читалачко „сурфовање“ у романима Владимира Тасића. Индикативан је наслов књиге Радослава Петковића Византијски интернет (2007) који упућује на нове изворе знања па према томе и нове могућности заснивања жанра историјског романа, присутне у Пет- 
ковићевом делу Савршено сећағе на смрт (2008). Док роман Гордане Ћирјанић Оно што одувек желиш (2010) тематизује актуелну позицију човековог отућења у свету који креирају телевизијски програми, први српски

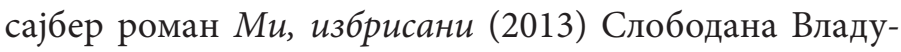
шића прати судбину јунака у виртуелним, рачунарски генерисаним световима новог миленијума.

Историја свакако остаје преокупација савременог романа. Док је историографска метафикција своје тематско и смисаоно упориште налазила у прошлим вековима, поготову у средњем веку и бароку, новији романи се изразитије фокусирају на актуелне политичке и идеолошке прилике. Док је у Албахаријевом Снежном човеку, па и у романима Владимира Тасића, Срђана Ваљаревића или Драгана Великића проговорило искуство одласка као (не)могућег бекства од дуге сенке балканске историје дотле се у Басариној Уклетој земљи (1995) артикулише ужас останка у гротескном свету милошевићевског доба. На тој линији политичке сатире успоставиће се у новом веку широки спектар сатиричне а често и ангажоване прозе у распону од пародија Милете Продановића до травестија Зорана Ћирића и нео-панк прозе Марка Видојковића. Виђење историје, поготову збивања у двадесетом веку, кроз метафоре болести и лудила изразито је у новијем роману, од Басариног Успона и пада Паркинсонове болести (2006) до Гаталичиног Великог рата и Лузитаније (2017) Дејана Атанацковића.

Као што се завршна деценија деветнаестог века у нашим књижевноисторијским одређењима посматра као зачетак модерне, тог првог периода модернизма у двадесетом веку, изгледа да се, бар за сада, последња деценија двадесетог века указује као раздобље у којем се може тражити доња граница периодизацијског од- 
ређења савремене српске књижевности. Како ћемо је назвати, још је отворено питање али оно се не мора нужно и одмах разрешити; битнија је, чини се, свест о променама које су се у готово свим доменима друштва, уметности и културе тада одиграле. Очигледно је да се не само српска књижевност него и наше друштво у новом веку, још увек опсесивно бави неким болним питањима с краја прошлог столећа. Теме емиграције, кризе вредности, ратова, дестабилизованог индивидуалног и националног идентитета, бомбардовања и лудила историје доминантне су у нововековном роману.

Идеал сваког књижевноисторијског проучавања, ако се данас у науци о књижевности уопште може говорити о некаквом идеалу, и даље би могао бити онај који је историчару идеја поставио Валтер Бењамин „из удаљених екстрема, привидних ексцеса у развоју, обелоданити конфигурацију идеје као тоталитета обележеног могућношћу једног смисленог упоредног постојања таквих супротности" (Benjamin 1989: 24). Конституисање тог могућег тоталитета у двадесет и првом веку додатно је отежано хиперпродукцијом књига која је једно од суштинских обележја савременог доба које ће, како ствари стоје, захтевати неке сасвим нове технике читања, селекције, разврставања, тумачења и повезивања књижевне грађе.

\section{ЛИТЕРАТУРА}

Badiou, Alain. The Century, prev. Alberto Toscano, Cambridge; Polity Press, 2007.

Benjamin, Walter. Poreklo nemačke žalobne igre, prev. Javorka Finci, Sarajevo: Veselin Masleša, 1989.

Virilio, Paul. From Modernism to Hypermodernism and Beyond, London: Thousand Oaks, 2000. 
Брајовић, Тихомир. Кратка историја преобиља, Зрењанин: Агора, 2009.

Дамјанов, Сава. Шта то беше српска постмодерна?, Београд: Службени гласник, 2012.

Ђорђић, Стојан. Иреалистичко доба: Српска книжевност од 1990. до 2010, Београд: Службени гласник, 2015.

Eko, Umberto. O književnosti, prev. Milana Piletić, Beograd: Narodna knjiga, 2002.

Епштејн, Михаил. Постмодернизам, прев. Радмила Мечанин, Београд: Цептер, 1998.

Јерков, Александар. Антологија српске прозе постмодерног доба, Београд: Просвета,1991.

Недић, Марко. Повратак причи: Огледи о савременој српској причи, Нови Сад: Академска књига, 2017.

Петковић, Новица. Словенске пчеле у Грачаници, Београд: Завод за уџбенике, 2007.

Скерлић, Јован, Историја нове српске кюижевности, Београд: Рад, 1953.

Hačion, Linda. Poetika postmodernizma, prev. Vladimir Gvozden, Ljubica Stanković, Novi Sad: Svetovi, 1996.

Hobsbum, Erih. Doba ekstrema, prev. Predrag J. Marković, Beograd: Dereta, 2002.

\section{Predrag Petrović}

\section{SERBIAN NOVEL IN THE NEW CENTURY}

\section{Summary}

The paper discusses the issues of periodization of contemporary Serbian literature. It's a period since the last decade of the twentieth century to the present. The paper examines whether this period has its literary and historical character, whether it can be more precisely named, and, finally, what are its leading poet- 
ic tendencies and authors. The creative currents in the Serbian prose at the transition of the century are observed in relation to the established postmodernist paradigm, as its continuation, the modification or rejection. Serbian literature, like our society in the new century, is still obsessively concerned with some painful issues from the end of the last century. The themes of emigration, the crisis of values, wars, destabilized individual and national identity, bombing, the ultimate madness of history are still dominant in the modern novel.

Key Words: contemporary literature, novel, poetry, postmodernism, history. 